\title{
The essential oil content of Salvia officinalıs in Konya grown
}

\author{
Hayriye Alp \\ Necmettin Erbakan University, GETAT CENTER, Konya, Turkey.
}

Corresponding Author: Hayriye Alp, Necmettin Erbakan University, GETAT CENTER, Konya, Turkey.

Received date: June 01, 2021; Accepted date: June 21, 2021; Published date: July 15, 2021

Citation: Hayriye Alp (2021) The essential oil content of Salvia officinalıs in Konya grown. J, Biotechnology and Bioprocessing. 2(6); DOI: $10.31579 / 2766-2314 / 046$

Copyright: ( $)$ 2021, Hayriye Alp, This is an open access article distributed under the Creative Commons Attribution License, which permits unrestricted use, distribution, and reproduction in any medium, provided the original work is properly cited.

\begin{abstract}
Sage has been used for centuries as a sacred herb in Roman rituals to extend life, especially in china. The positive effects of the plant on health have been described frequently from the ancient Roman period until the middle ages. It is used for the treatment of bronchial infections, colds and cough. It is also traditionally used to relieve gastraintestinal symptoms such as dyspepsia, gas, indigestion, bloating. In the treatment of excessive sweating in menopause. It has been shown to be effective. Its effectiveness is used as a mouthwash in the irritation of the oral mucosa as well as in pharyngitis, tonsillitis, gingivitis, glossitis infections. These teas used in treatment are prepared as infusion, decoction and cold maceration. S. officinalis plant grown in July Organic Farm in Akyokuş region in Konya province was used. The analyzes were carried out in the Western Mediterranean Agricultural Research Institute Directorate Medical and Aromatic Plants Center Laboratory in 2017. Approximately $20 \mathrm{~g}$ of dried plant material prepared for analysis. The sample is weighed. The weighed sample is placed in the glass clevenger flask. Approximately 10 times $(200 \mathrm{ml})$ of pure water is added to the sample. It is subjected to hydrodistilation process for about 2 hours. Then the reading of the essential oil sample, which accumulates in the graduated part and creates a phase difference with water, is taken and the result is recorded in $\mathrm{ml}$. Then, based on the weight, the amount of essential oil is calculated as a percentage. In our study, $\alpha$-tujone $24.48 \%$, camphor $16.45 .1 .8 \%$ cineol $12.38 \%$, while viridiflorol was found as $6.5 \%$. We think that the differences may be due to differences in geographical regions and precipitation. Ventilatory oil ratios have been shown in course studies that ontogenetic factors can also be affected by many factors.
\end{abstract}

Key words: salvia officinalis,essential oil, content

\section{Introduction}

Sage has been used for centuries as a sacred herb in Roman rituals to extend life, especially in China. The positive effects of the plant on health have been described frequently from the ancient Roman period until the middle ages. It is used for the treatment of bronchial infections, colds and cough. It is also traditionally used to relieve. Gastraintestinal symptoms such as dyspepsia, gas, indigestion, bloating. In the treatment of excessive sweating in menopause. It has been shown to be effective. Its effectiveness is used as a mouthwash in the irritation of the oral mucosa as well as in pharyngitis, tonsillitis, gingivitis, glossitis infections. These teas used in treatment are prepared as infusion, decoction and cold maceration $(1,2,3,4)$.

In this study, we tried to determine the essential oil content of Salvia officinalis grown in Konya for 2017.

\section{Method}

S. officinalis plant grown in July Organic Farm in Akyokuş region in Konya province was used. The analyzes were carried out in the Western Mediterranean Agricultural Research Institute Directorate Medical and Aromatic Plants Center Laboratory in 2017. Approximately $20 \mathrm{~g}$ of dried plant material prepared for analysis. the sample is weighed. The weighed sample is placed in the glass clevenger flask. Approximately 10 times
(200 ml) of pure water is added to the sample. It is subjected to hydrodistilation process for about 2 hours. Then the reading of the essential oil sample, which accumulates in the graduated part and creates a phase difference with water, is taken and the result is recorded in $\mathrm{ml}$. Then, based on the weight, the amount of essential oil is calculated as a percentage.

The amount of essential oil is specified as the amount of substance defined as milliliters in $100 \mathrm{~g}$ of anhydrous plant obtained by distillation under the conditions specified in this standard. The principle of this method is to distill the aqueous suspension of the sample, collect the distillate in a graduated tube with a certain volume of xylene used to hold the essential oil, wait for the separation of the organic and aqueous phases, read the total volume of the organic phase, and calculate the volatile oil after extracting the xylene volume.

\section{Gas Chromatography Mass Spectrometry Analysis}

The components of essential oils have been determined in the West Mediterranean Agricultural Research Institute / Medical Research Center Laboratory with the GC / MS device given below. Samples were diluted 1: 100 with hexane for analysis. The essential oil component analysis of the samples was carried out using GC / GC-MS (Gas chromatography (Agilent 7890A) -mass detector (Agilent 5975C)) using a capillary 
column (HP Innowax Capillary; $60.0 \mathrm{~m}$ x $0.25 \mathrm{~mm}$ x $0.25 \mu \mathrm{m}$ ). Helium was used as carrier gas at a flow rate of $0.8 \mathrm{ml} / \mathrm{min}$ in the analysis, and samples were injected into the device as $1 \mu \mathrm{l}$ at a split ratio of 40: 1 . The injector temperature was kept at $250{ }^{\circ} \mathrm{C}$, the column temperature program was set to be $60^{\circ} \mathrm{C}$ (10 minutes), $20^{\circ} \mathrm{C} /$ minute and $250^{\circ} \mathrm{C}(10.5$ minutes) from $60^{\circ} \mathrm{C}$ to $250^{\circ} \mathrm{C}$. In line with this temperature program, the total analysis time was 30 minutes. Scanning range $(\mathrm{m} / \mathrm{z}) 35-450$ atomic mass units and electron bombardment ionization $70 \mathrm{eV}$ were used for the mass detector. In the diagnosis of essential oil components, the data of WILEY and OIL ADAMS libraries were taken as basis. Component percentages of the results were made using the FID detector, and the diagnosis of the components was made using the MS detector.

\section{Results}

Essential oils are the effective ingredients of most of the important medicinal and aromatic plants produced in the world (5). The ratio of essential oils, an important secondary metabolite for plants, varies depending on many factors. On the ratio of essential oils; The genotype of the plants used in production, the climate and soil characteristics of the region where the production is made and the cultivation techniques are effective (6). One of the most important cultivation techniques that affect the rate of essential oil is when the plants are harvested. Studies have shown that the proportion of essential oil that aromatic plants contain varies depending on the growth period of the plant $(7,8,9)$. This is of great importance for manufacturers who want to produce standard quality products. Because even if all the production-related applications are fulfilled completely, the harvest at the wrong time affects the essential oil content of the product negatively. This decreases the market value of the product. In order to eliminate this negativity, it is necessary to determine the most appropriate harvest times of the aromatic plants to be produced according to the production regions.

\begin{tabular}{|c|c|c|c|c|c|}
\hline \multicolumn{5}{|c|}{ YAPILAN ANALIZ } & $\begin{array}{l}\text { ANALIZ } \\
\text { METODU }\end{array}$ \\
\hline \multicolumn{5}{|c|}{ Toplam Uçucu Yağ Miktarı } & Hidrodistilasyon \\
\hline \multicolumn{5}{|c|}{ Uçucu Yağ Bileşimi } & GC-MS/FID \\
\hline \multicolumn{6}{|c|}{ ANALIZ SONUCLARI } \\
\hline \multicolumn{6}{|c|}{ Toplam Uçucu Yağ Miktarı (\%): 1,83} \\
\hline No & Bileşen adı & $\begin{array}{c}\text { Bileşen } \\
\text { miktari } \\
(\%)\end{array}$ & No & Bileşen adı & $\begin{array}{c}\text { Bilesen } \\
\text { miktarı } \\
(\%)\end{array}$ \\
\hline 1 & $a$-Pinene & 4,48 & 10 & Linalool & 0,68 \\
\hline 2 & Camphene & 4,31 & 11 & Bornyl acetate & 2,48 \\
\hline 3 & $\beta$-Pinene & 2.58 & 12 & $\beta$-Caryophyllene & 3,67 \\
\hline 4 & Myrcene & 0.90 & 13 & $a$-Humulene & 3,84 \\
\hline 5 & Limonene & 1,38 & 14 & Borneol & 3,65 \\
\hline 6 & 1,8-Cineole & 12,38 & 15 & Humulene epxide II & 0.56 \\
\hline 7 & $\alpha$-Thujone & 24,48 & 16 & Viridiflorol & 6,50 \\
\hline 8 & $\beta$-Thujone & 7,84 & 17 & Manool & 3,82 \\
\hline 9 & Camphor & 16.45 & & & \\
\hline
\end{tabular}

Table1.salvia officinalis essential oil analysis.

The parts of sage used as drugs are leaves (Folia Salviae), flowers (Flores Salviae) and essential oil (Oleum Salviae) obtained from leaves and flowers, and the most important bioactive substance is the essential oil they contain (10). While the rate of essential oil in the fresh leaves of the plant is around $0.38 \%$, this rate varies between $0.50-2.50 \%$ in drug leaves $(12 ; 14)$. In the codex, the essential oil ratio is required to be at least $1.5 \%$ (13).

In the Karayel study, the main components of the essential oils in sage analyzes grown in Kütahya ecology were $\alpha$-thujone $26.56 \%$, 1.8-Cineole $14.01 \%$, Viridiflorol $14.67 \%$; The second form was made in autumn and the main component was $\alpha$-thujone $39.51 \%$, Camphor $20.22 \%, 1.8$ Cineole $10.27 \%$. The substance desired to be obtained was determined as $\alpha$-thujone (39.51\%)(15).

In our study, $\alpha$-tujone $24.48 \%$, camphor $16.45 .1 .8 \%$ cineol $12.38 \%$, while viridiflorol was found as $6.5 \%$. We think that the differences may be due to differences in geographical regions and precipitation. Ventilatory oil ratios have been shown in course studies that ontogenetic factors can also be affected by many factors.

The proportion and components of essential oils of medicinal and aromatic plants change under the influence of the environment, genetic factors, and aquaculture practices (16). Likewise, the rate and composition of essential oils of aromatic plants differ depending on the developmental period of the plants. Considering this situation, when cultivating aromatic plants, it is of great importance to harvest the plants at the appropriate time in order to obtain the most essential oils and oils with the essential oil composition that are most suitable for the purpose of production.

The leaf drop of Salvia officinalis is registered with the European Pharmacopoeia and has a positive monograph of the German E commission. It contains tujon. Salvia triloba leaf drogu is similar to salvia officinalis leaves in terms of chemical structure and treatment. Salvia triloba is used instead of medicinal sage since it does not grow naturally in Turkey. This strain, which contains traces of tujon, is also included in the European pharmacopoeia. The drug of both medicinal plants is accepted as medicinal sage in the scientific platform.

\section{Content and feature}

The essential oil of Salvia officinalis contains 50-30\% tujon and isotujon in a mixture. This mixture is cytotoxic. The essential oil is $1.5-2.5 \%$. According to the European pharmacopoeia, the whole drug is required to contain at least $1.5 \%$ essential oil and the chopped drug at least $1 \%$. Essential oil is mainly composed of monoterpenes. It is desirable that it contains essential oil. Essential oil consists mainly of monoterpenes. It contains $30-50 \%$ tujone in its structure.It contains $20-35 \%$ camphor and 5-15\% 1.8 cineol (eucalyptol) as well as borneol and bornyl acetate 6$15 \%$ sesquiterpenes. Hydroxytarcino acid derivatives are $2-6 \%$ and are called Lamiaceae tannin compounds.Diterpene is the main component carnosolic acid (salvin) as bitter substances, besides rosmanol and isorosmanol. Flavonoids are 1-3\% Phenol glycosides cafeoyl-fructosyl glycoside, cafeoyl-apiosyl glycoside As triterpenes, the main ingredient is ursolic acid. There are also polysaccharides. 
In Salvia triloba, the essential oil is 2-3.5\%. According to the European pharmacopoeia, the whole drug is required to contain at least $1.8 \%$ essential oil and the chopped drug at least $1.2 \%$. It contains 1.8 cineol at a rate of $1.8 \%$. Apart from this, it contains less than $1 \%$ tujon, $1.5-2.4 \%$ camphor and monoterpenes, sesquiterpenes. Hydroxitarcin acid derivatives are 5\%. Lamicae are known as tannin compounds. Rosmarinic acid is predominant. Mainly carnosol (picrosalvin) and rosmanol are found. Flavonoids are $2 \%$. It consists mainly of flavones (salvigenin). As triterpenes, the main component is ursolic acid (4).

\section{Effect and use}

The usage of Dalmatian sage and Turkish sage show the same properties. It is used in colds, tonsillitis, pharyngitis. When using the infusion should be careful not to be hot. It is used as a gargle every 2 hours. It has bactericidal effects as it is herbal relaxing. It has spectrum. It is antibacterially effective against gram (+) and gram (-) bacteria as well as fungi, especially candida albicans.

The antibacterial effect of Dalmatian tea has been shown that carnosolic acid, which is a diterpene bitter substance, prevents replication by affecting the RNA synthesis in bacteria. Although this effect is also in Turkish sage, the study was made with Dalmatian sage and has an antibiotic effect. Sage, which also has antiviral properties, is especially used in vesiculobullous stomatitis of herpes simplex viruses. 1,8 cineol found in both sage also gives expectorant property. According to recent studies, it is known that topical anti-inflammatory effects are mostly caused by ursolic acid in inflammatory diseases of the mouth and throat area. the astringent effect has also been proven. It has antioxidant properties, it shows astringent properties thanks to its chlorogenic acid, ellaganic acid, epicatechin and epiglocatechingallate. The fields of use of Dalmatian sage, approved according to the German E commission, include dyspeptic diseases, feeling of fullness, mild gastrointestinal cramps, treatment of hyperhidrosis and mouth throat mucosa diseases. As approved by the commission $\mathrm{E}$ of Dalmatian sage, it has antiperspirant properties, not increasing perspiration, contrary to its traditional use.

\section{Dosage and use}

4-6 g / day should be used internally. Infusion of 1 teaspoon of sage leaves with $150 \mathrm{ml}$ of hot water as a medicinal tea is prepared, kept for 10-15 minutes with the top covered, and infused. The reason for the long duration of this period is to allow the bacteriostatic effective tannin compounds to pass into the water. In this way, it is accompanied by astringent effect; sips are drunk. This medicinal tea is also used as mouthwash for stomatitis and gingivitis. It is especially recommended for mouth and throat infections and herpes viruses. If it is used more than $15 \mathrm{~g}$ daily dose, it may cause tachycardia, hot flushes, and dizziness, depending on its content.

Dalmatian sage is contraindicated in epileptic patients during pregnancy and lactation due to the thujone it contains. It can only be used as mouthwash after the fourth month of pregnancy, not exceeding 2 times a day, and for a total of 4 weeks (4).

\section{Conclusion}

The chemical compositions of essential oils of aromatic plants differ under the influence of the genotypes of the plants used in production, the ecological conditions of the production area and the cultivation practices. One of the factors affecting the change in essential oil composition is the plant growth period when the harvest is made. The ratio of essential oil components in plants varies greatly depending on the developmental period in which the harvest is made. This change is more noticeable in the main components that make up the essential oil. In this study, the main components of the essential oil of medicinal sage, alpha-thujone, camphor, bornyl acetate, germakrene, and 1.8-cineol varied depending on the different developmental stages during the harvest. This situation can be explained by the effect of the environmental conditions changing depending on the growth stages of the plant on the physiological state (biosynthesis path) of the plant and the aging that occurs in the plant organs with the progression of the vegetation period $(5,9)$.

\section{References}

1. Saad B Said O(eds) commonly used herbal medicine in the mediterranean.1n:greko-arab and sslamic herbal medicine pp.149227.Hoboken:john wiley\&sons.inc.

2. Amin A.AlkaabiA,Al-Falasi S,Daoud S(2005) Chemopreventive activities of trigonella foenum graecum(fenugreek) against breast cancer. Cell biol int 29:687-694.

3. Sar S. (2019) Folk Medicine Practices in Anatolia.

4. Zeybek A.U. Özgüç S. (2019) Rational and modern phytotherapy.pp.World Medicine bookstore.1.st edit.1sbn.978605-9615-35-8pp.204-207

5. Mammadov R., (2014) Secondary Metabolites in Seed Plants. Nobel Academic Publishing, Ankara.

6. Hadiana J., Tabatabaeia SMF., Naghavib MR., Jamzadc Z and Ramak-Masoumia T., (2008) Genetic diversity of Iranian accessions of Satureja hortensis L. based on horticultural traits and RAPD markers. Scientia Horticulturae, 115(2): 196-202

7. Toncer O., Karaman S., Kizıl S ve Diraz E., (2009) Changes in essential oil composition of oregano (Origanum onites L.) due to diurnal variations at different development stages. Notulae Botanicae Horti Agrobotanici ClujNapoca, 37(2): 177-181.

8. Uyanık M ve Gurbuz B., (2015) Effect of ontogenetic variability on essential oil content and itts composition in lemon balm (Melissa officinalis L.). Journal of Tekirda $\breve{g}$ Agriculture Faculty, 12 (1): 91-96.

9. Lakusic BS., Ristic MS., Slavkovska VN., Stojanovic DL and Lakusic DV., (2013) Variations in essential oil yields and compositions of Salvia officinalis (Lamiaceae) at different developmental stages. Botanica Serbica, 37(2): 127-139.

10. Başa AG., Roman GV., Ion V., Toader M and Epure LI., (2012) Research on productivity and yield quality of Salvia officinalis L. species grown in organic agriculture conditions. Scientific Papers Series A Agronomy, LV: 271- 278.

11. Tugrul Ay S, Cinar O, Demiray K et al. (2012) Determination of Quality Characteristics of Dorystoechas hastata Species Collected from Nature in Antalya Flora. Medical and Aromatic Plants Symposium (Proceedings), 374.

12. Ekren S.Sönmez Ç.Sancaktaroğlu S. Bayram E. (2007) Determination of the Effects of Different Shape Heights on Agronomic and Technological Properties of Sage (Salvia officinalis L.) Genotypes. Volume 44 , Issue 1, Pages 55 - 70

13. Y1lmaz D. Gökduman ME. (2015) Determination of PhysicoMechanical Properties of Sage (Salvia Officinalis) Plant at Different Humidity Levels. Volume 10 , Issue 1, Pages 73 - 82

14. KarayelHB. (2019) Evaluation of Essential Oil Components in Medicinal Sage (Salvia officinalis L.) Flowers Grown in Kütahya (Çavdarhisar) Region. European Journal of Science and Technology. Archive. No. 16PP.266-534. doi.org/10.31590/ejosat.536961

15. Hadiana J., Tabatabaeia SMF., Naghavib MR., Jamzade $Z$ and Ramak-Masoumia T., (2008) Genetic diversity of Iranian accessions of Satureja hortensis L. based on horticultural traits and RAPD markers. Scientia Horticulturae, 115(2): 196-202. 